UDC 539.3

\title{
STUDY OF PARAMETERS OF NONLINEAR SLOPE DEFORMATION UNDER THE ACTION OF POWER AND NATURAL FACTORS
}

\author{
I.I. Solodei, \\ DSc, Department of Structural mechanics \\ E.Yu. Petrenko, \\ $\mathrm{PhD}$, Department of Geotechnics \\ Gh.A. Zatyliuk, \\ $\mathrm{PhD}$, Department of Structural mechanics \\ Kyiv National University of Construction and Architecture \\ Povitroflotskyj av., 31, Kyiv, 030370
}

DOI: $10.32347 / 2410-2547.2021 .107 .35-44$

\begin{abstract}
On the example of construction of a three-storey cottage on a landslide-prone slope, the analysis of the operating conditions of existing anti-landslide structures was carried out and their role in ensuring the slope stability was determined. The efficiency of the proposed calculation method [6] based on the finite element method (FEM) is shown, taking into account the theory of reinforced soils.

Keywords: finite element method, semi-analytical finite element method, landslide-prone areas, slope stability, engineering protection of the territory.
\end{abstract}

Construction planning in complex engineering and geological conditions, which include landslide-prone areas, requires a detailed analysis of the existing state of the slope and the forecast of its behavior depending on changes in natural and technogenic factors [1]. This possibility can be provided only by modeling of deformation processes using numerical calculation methods $[2,5]$.

As an example, consider the unfinished construction of a three-storey cottage. According to the materials of engineering surveys in the geological structure of the site are involved the quaternary sandy-clay deluvial, swamp, aeolian-deluvial, fluvioglacial sediments, covered with the layer of vegetation and loose soils. The entire thickness of the quaternary sediments is covered with the spondylar loams and clays of the Kyiv tier. In the upper part of the section there are loess sands and loams that are sedimentary. The construction of the slope is made with the insert into the slope. The depth of the foundations, therefore, is variable. Buildings with external and internal loadbearing walls can be attributed to a relatively rigid structural scheme. Additional rigidity is provided by reinforced concrete straps, which are arranged on the walls within the ceiling above the basement, the first and the second floor. Foundations are tape, with a monolithic reinforced concrete foundation slab. The average pressure on the sole of the foundations is $125 \ldots 150 \mathrm{kPa}$, which does not exclude the possibility of subsidence when soaking the base in some parts of the foundations. 
Hydrogeological conditions of the exploration site are characterized by the presence of the sustained aquifer, which is associated with the location of the thalweg beam. It is confined to sandy-clay soils: EGE-2, 3, 4a, 5, 6, 7, 8upper, weathered fractured zone (Fig. 1, Table 2) and was met depending on the terrain at the depths of $0.5 \ldots 12.1 \mathrm{~m}$. The flow of groundwater is directed towards the thalweg. Within the construction site, the groundwater level drops to $3.5 \mathrm{~m}$, which confirms that these waters are supplied by the plateau. The general waterproof layer for the aquifer is the not weathered zone of spondylar clays of the Kyiv tier.

The data of engineering and geological surveys show that during the construction of buildings the natural moisture of the forest layer at the appropriate depths (from 2.0 up to $7.0 \mathrm{~m}$ ) increased from $4 . . .6 \%$ in the upper part of the site to $11 \ldots 14 \%$. In the lower part of the site at the appropriate depths (from 7.0 up to $11.0 \mathrm{~m}$ ) the natural moisture increased from $9 . .12 \%$ to $16 \ldots 19 \%$. Therefore, the arrangement in the upper part of the slope of the retaining wall without drainage and the house itself led to a change in the natural ways of unloading surface and groundwater on the slope.

The preliminary calculation of the slope stability was performed by the method of round cylindrical sliding surfaces [3] for soils of natural humidity and in water-saturated state. The following minimum slope stability coefficients were obtained: for soils of natural moisture Kst $=1.38$, for water saturation $\mathrm{Kst}=1.22$.

The method of round cylindrical surfaces is a simplified method of calculating the slopes stability, which in the conditions of heterogeneous layered slope leads to the overestimation of its stability. Therefore, to determine the actual NSDT of the slope, the calculation profile was developed (Fig. 1) on which several formulations of the above problem were performed (Tab. 1).

Table 1

\begin{tabular}{|c|l|}
\hline Formulation & \multicolumn{1}{c|}{ Formulation description } \\
\hline 1 & Net weight $(\mathrm{q})$, natural condition of soils \\
\hline 2 & $\begin{array}{l}\text { Net weight }(\mathrm{q})+\mathrm{RW} \text { No. 1 }(\mathrm{h}=3.5 \mathrm{~m})+\text { structure weight }(\mathrm{q} 2), \\
\text { natural condition of soils }\end{array}$ \\
\hline 3 & $\begin{array}{l}\text { Net weight }(\mathrm{q})+\mathrm{RW} \text { No. } 1(\mathrm{~h}=3.5 \mathrm{~m})+\text { structure weight }(\mathrm{q} 2)+\text { load } \\
\text { from the road surface and transport }(\mathrm{q} 1), \text { water-saturated soils }\end{array}$ \\
\hline
\end{tabular}

\footnotetext{
$*_{\mathrm{q}}-\mathrm{is}$ determined by the physical and mechanical characteristics of soils;

$\mathrm{q} 1$ - is the pressure from the road surface and transport $20 \mathrm{kPa}$;

$\mathrm{q} 2$ - is the pressure from the structure weight $125 \mathrm{kPa}$.
}

The calculation was performed on the basis of the developed methodology presented in the works [6,7]. The stress-strain state (SSS) of the slope is considered using the finite element method (FEM) and its torque circuit. The base is presented in the form of a modified model of fortified soils with the criterion of the limit state of Mises-Schleicher-Botkin. In numerical implementation, the slope on the basis of engineering surveys was presented as a finite-element discrete model with an elemental grid, a fragment of which is a separate engineering-geological element (Tab. 1). 
Table 2

\begin{tabular}{|c|l|c|c|c|c|c|}
\hline $\begin{array}{c}\text { No } \\
\text { EGE }\end{array}$ & \multicolumn{1}{|c|}{$\begin{array}{c}\text { Description } \\
\mathrm{MPa}\end{array}$} & $v$ & $\rho^{*}, \mathrm{~g} / \mathrm{cm} 3$ & $c, \mathrm{kPa}$ & $\begin{array}{c}\varphi, \\
\text { grade }\end{array}$ \\
\hline 1a & Bulk layer & 6 & 0.3 & $1.76 / 1.96$ & $25.4 / 11.7$ & $17 / 10$ \\
\hline 1 & Vegetable layer & 5 & 0.3 & 1.46 & $25.4 / 11.7$ & $17 / 10$ \\
\hline 2 & Plastic sandy loam & 6 & 0.32 & 1.86 & 5 & 14 \\
\hline 3 & Soft-plastic loam & 8 & 0.35 & 1.83 & 6 & 16 \\
\hline 4 & Loess sandy loam, hard & $20 / 9$ & 0.32 & $1.6 / 1.95$ & $23.3 / 9.9$ & $17 / 8$ \\
\hline $4 \mathrm{a}$ & Loess sandy loam, plastic & 9 & 0.32 & 1.83 & 9.9 & 8 \\
\hline 5 & Loess loam, tough-plastic & 7.4 & 0.35 & 1.85 & $17.7 / 4.9$ & $13 / 9$ \\
\hline 6 & $\begin{array}{l}\text { Plastic sandy loam, with sand } \\
\text { layers }\end{array}$ & 10 & 0.32 & 1.9 & $7 / 3.3$ & $18 / 9$ \\
\hline 7 & $\begin{array}{l}\text { Fine sand, saturated with } \\
\text { water, of medium density }\end{array}$ & 25 & 0.30 & 1.98 & 0.01 & 28 \\
\hline 8 & Semi-hard loam, «Kyiv marl» & 11 & 0.38 & 1.89 & 58 & 15 \\
\hline
\end{tabular}

* natural soil moisture/soils in water-saturated state

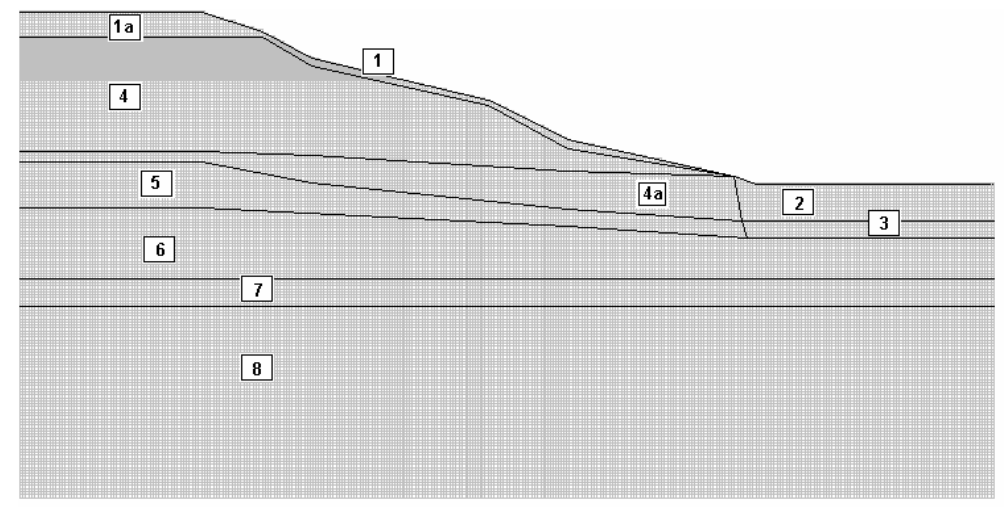

Fig. 1. Calculation profile EGE

The supports of the foundations A, B, C, D of the house are sequentially placed from the top of the slope to the bottom (Fig. 2). At the first stage, the problem of determining the stress-strain state of the slope from the own weight of the soil was solved, which was taken as the basic one for further calculations.

On Fig. 2 and 3 are shown the isolines of the intensities of plastic deformations for soils in the natural state and at their water saturation, respectively. With it, the horizontal displacements U1 of the control points of the slope in the natural state (RW No. 1, supports A, B, C and D), which corresponds to the formulation 2, are in the range of $0.5-0.65 \mathrm{~cm}$ (Fig. 4). But at water saturation (formulation 3), increase by orders and reach $29-30 \mathrm{~cm}$. 


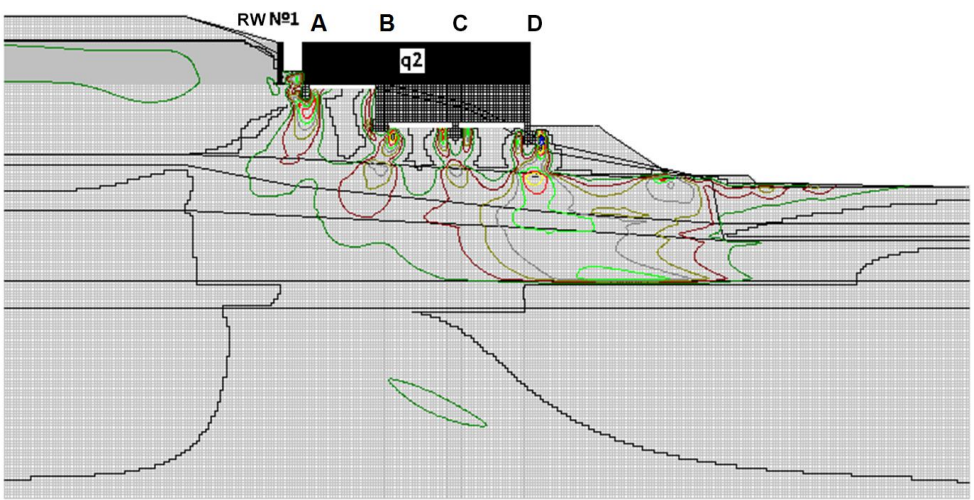

Fig. 2. Isolines of the intensities of plastic deformations $0 \div 0.6 \%$, natural soil moisture, formulation 2

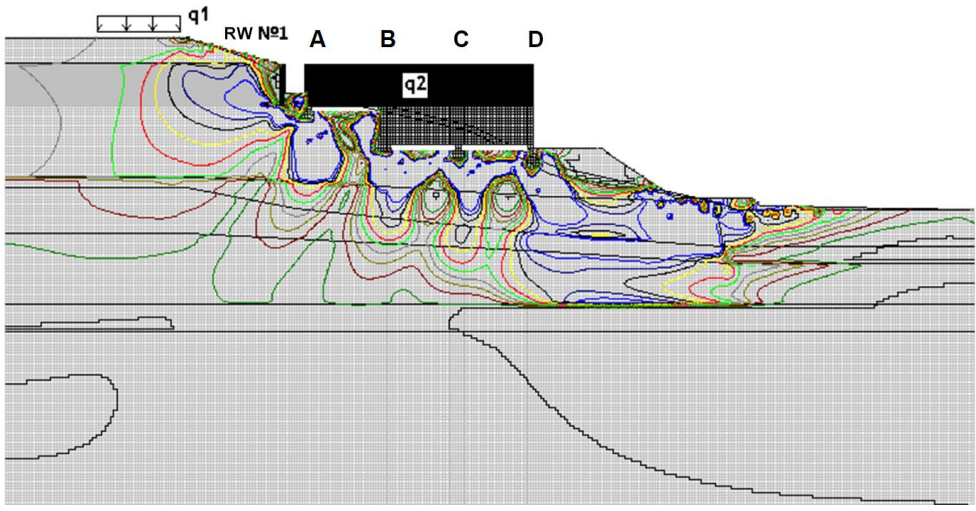

Fig. 3. Isolines of the intensities of plastic deformations from $0 \%$ and more $3 \%$, water-saturated soils, formulation 3

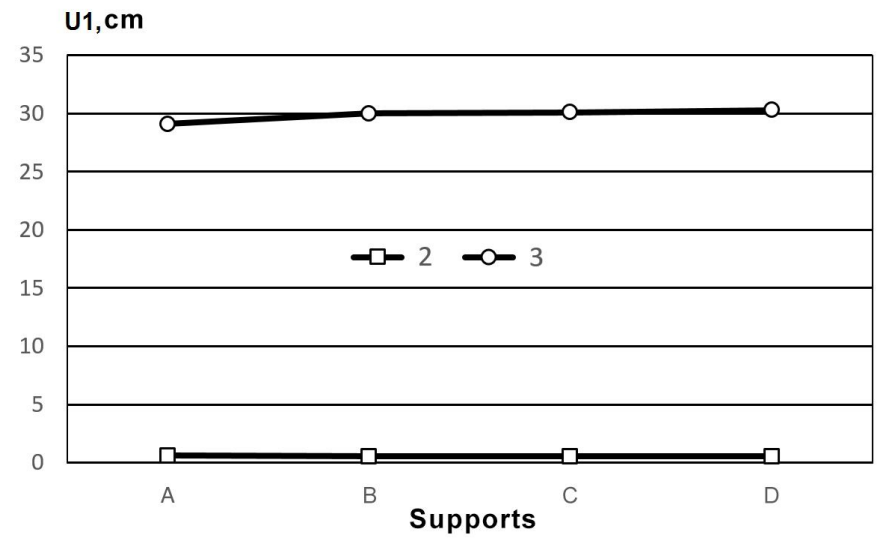

Fig. 4. Horizontal displacements of supports, formulations 2, 3 
The vertical displacements U2 of the supports are shown on Fig. 5. The uneven nature of the distribution $\mathrm{U} 2$ in the case of water saturation of the slope is explained by the presence of rotating components of the house as a rigid whole. With it the vertical displacements RW No. 1 for the natural state are equal to $3.4 \mathrm{~cm}$, water-saturated $-6.7 \mathrm{~cm}$.

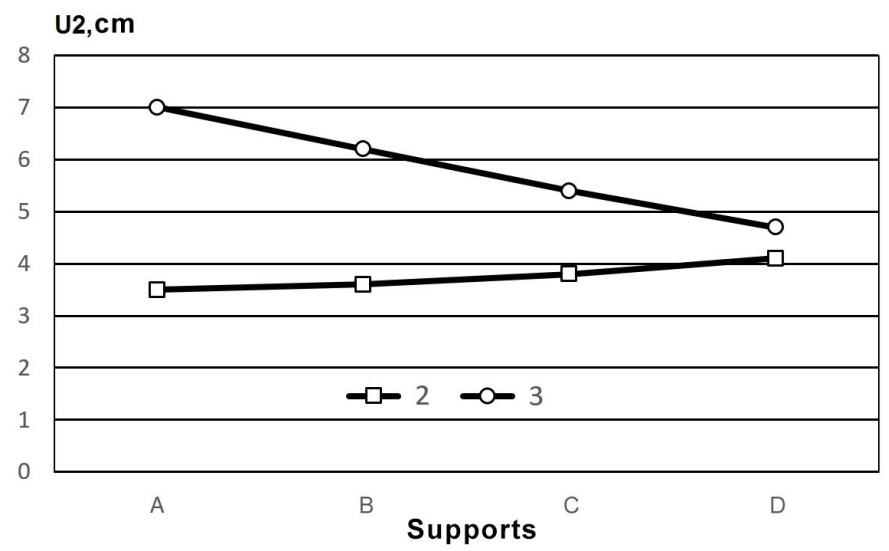

Fig. 5. Vertical displacements of supports, formulations 2,3

Therefore, it is seen that at natural moisture the base soils absorb the load and are deformed within acceptable limits. At full water saturation, the deformations of the soil base exceed the allowable normative values. In addition, the zones of plastic deformations are localized in a fairly narrow area with access to the day surface. The stability coefficients Kst obtained at the natural soil moisture (formulation 2) of the slope and at their water saturation (formulation 3 ) are 1.15 and 0.9 , respectively.

It is seen that even at natural soil moisture the slope does not have a normative margin of stability (Kst $<1.25)$. Potential sliding lines are localized on the roof EGE-6, have the beginning in the upper part of the slope and reach the day surface in the lower part (Fig. 2). When the soil is saturated with water, the sliding surface is localized above on EGE-5 (Fig. 3) with the beginning in the upper part of the slope and access to the day surface at its foot.

To overcome these problems, the design solutions were proposed in the form of replacement of RW No. $1(\mathrm{~h}=16 \mathrm{~m}, \mathrm{~d}=420 \mathrm{~mm})$ and the installation of an additional retaining wall RW No. $2(\mathrm{~h}=17 \mathrm{~m}, \mathrm{~d}=420 \mathrm{~mm})$ in the lower part of the slope (Tab. 3, Fig. 6).

Table 3

\begin{tabular}{|c|l|}
\hline Formulation & \multicolumn{1}{c|}{ Formulation description } \\
\hline 4 & $\begin{array}{l}\text { Net weight }(\mathrm{q})+\text { RW No. 1 + structure weight }(\mathrm{q} 2)+\text { load from the } \\
\text { road surface and transport }(\mathrm{q} 1), \text { water-saturated soils. }\end{array}$ \\
\hline 5 & $\begin{array}{l}\text { Net weight }(\mathrm{q})+\text { RW No. 1 + structure weight }(\mathrm{q} 2)+\text { RW No. } 2+ \\
\text { load from the road surface and transport }(\mathrm{q} 1), \text { water-saturated soils. }\end{array}$ \\
\hline
\end{tabular}




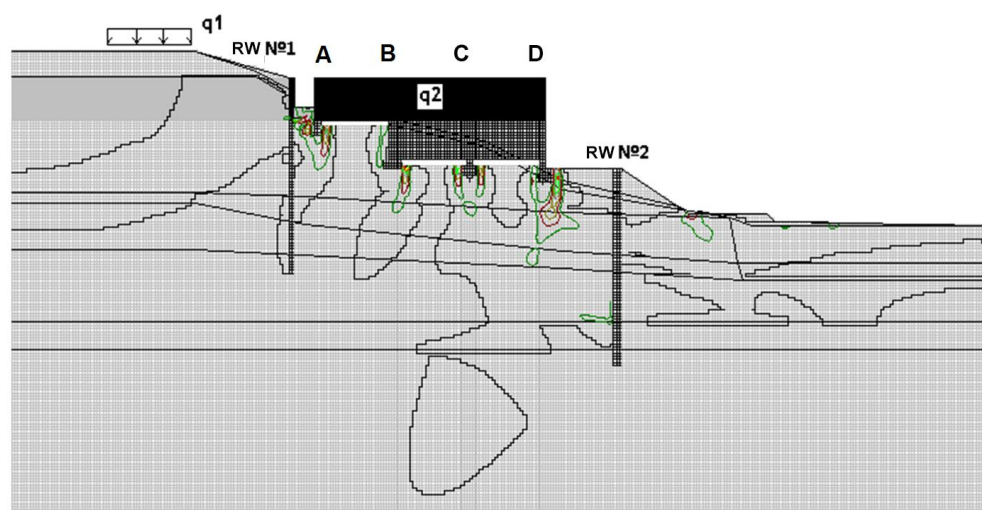

Fig. 6. Isolines of the intensities of plastic deformations $0 \div 0.6 \%$, water-saturated soils, formulation 5

With it, the horizontal displacements U1 of the supports are recorded within $0.9 \mathrm{~cm}$ for formulation 2 , and within $0.6 \mathrm{~cm}$ when installing RW No. 2 (Fig. 7). The walls themselves have the displacements of $0.7 \mathrm{~cm}$ and $0.35 \mathrm{~cm}$, respectively. The vertical displacements U2 of the supports do not exceed 3.2 $\mathrm{cm}$ in both cases (Fig. 8).

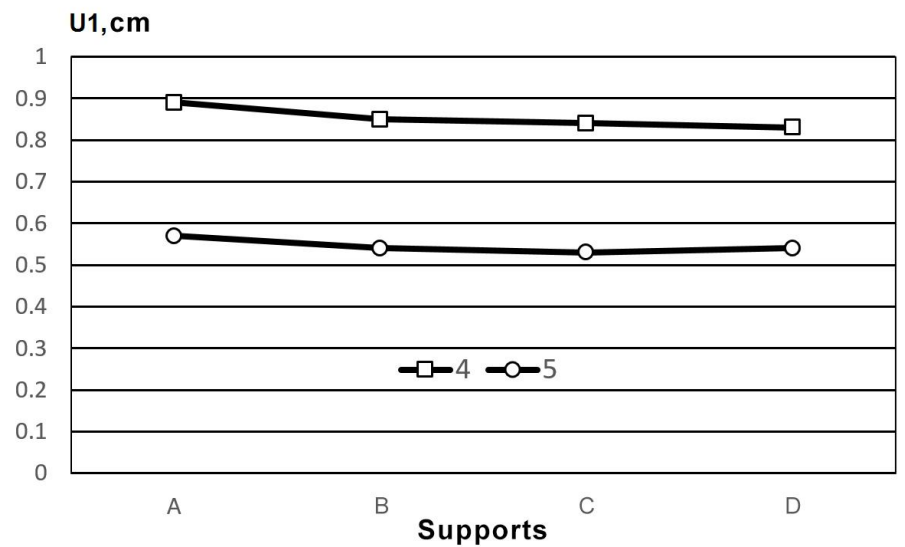

Fig. 7. Horizontal displacements of supports, formulations 4, 5

The engineering protection of this territory under the project was provided by the installation of retaining walls made of prefabricated concrete wall foundation blocks, which rest on a monolithic reinforced concrete slab and have reinforcing buttresses. This solution can be considered as a measure to relieve the horizontal pressure of the soil on the basement wall of the house from the side of the slope to keep the soil of limited volume, which cannot be considered as a retaining wall that increases the slope stability as a whole.

When installing the retaining walls RW No. 1 and RW No. 2 from a number of bored piles in the upper and lower parts of the slope, the plastic 
deformations are localized between them (Fig. 6). With it, the supports displacements of the house during water saturation of the slope soils actually reproduce the displacement of the existing state at natural soil moisture (see Fig. 4, 5 and 7,8).

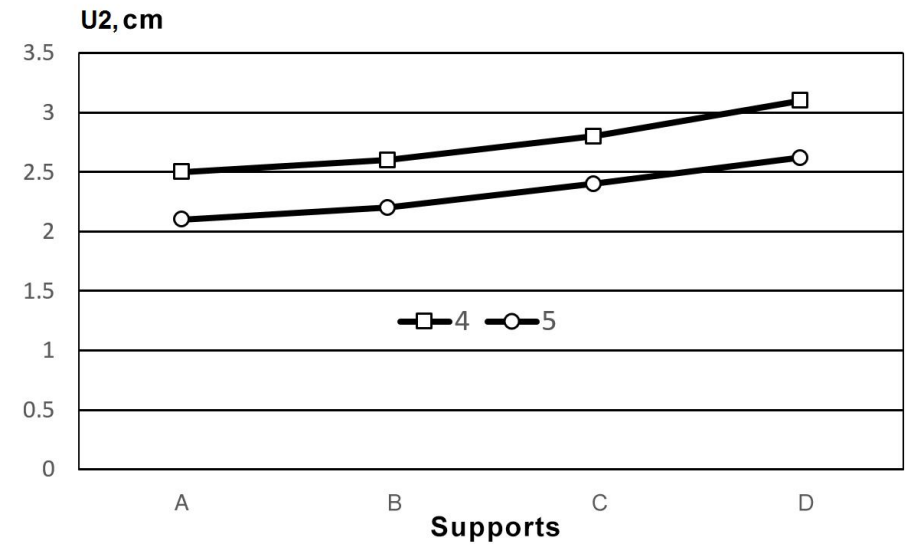

Fig. 8. Vertical displacements of supports, formulations 4,5

Therefore, the considered example of the method of calculation of the system «supporting structure-nonlinear base-house» gives the opportunity to give a reliable assessment of the territory state and offer a number of rational measures for its engineering protection, which ensures reliable operation of buildings and structures.

\section{REFERENCES}

1. Bileush A.I. Landslides and anti-landslide measures / A.I. Bileush - Kyiv: Naukova dumka, 2009.- $557 \mathrm{p}$.

2. Boiko I.P. Stress-strain state of elastic-plastic dilating base of pile foundations / I.P. Boyko // Osnovaniya i fundamenty. 1986. Issue.19. P. 10-12.

3. Recommendations for the choice of methods for calculating the slope stability coefficient and landslide pressure. - Moskva: Central'noe byuro nauchno-tekhnicheskoj informacii, 1986. $123 \mathrm{p}$.

4. Sakharov A.S. The moment scheme of finite elements taking into account rigid displacements / A.S. Sakharov // Soprotivlenie materialov i teoriya sooruzhenij. -1974. - Issue.24. - P. 147156.

5. Sakharov A.S. Finite Element Method in Solid Mechanics / A.S. Sakharov, V.N. Kyslookyi, V.V. Kyrychevskyi et al. - Kyiv: Vyshcha shkola, 1982.- 479 p.

6. Solodei I.I. Nonlinear problem of structural deformation in interaction with elastoplastic medium / I.I. Solodei, E.Yu. Petrenko, Gh.A. Zatyliuk // Strength of Materials and the Theory of Structures. - 2020. - Issue 105. - P.49-64.

7. Solodei I., Implementation of the linear elastic structure half-space in the Plaxis in the study of settlements / I. Solodei, Gh. Zatyliuk // Austrian Journal of Technical and Natural Sciences. 2020. Issue 9-10. - P. 36-38. 


\section{Солодей I.I., Петренко Е.Ю., Затилюк Г.А. \\ ДОСЛІДЖЕННЯ ПАРАМЕТРІВ НЕЛІНІЙНОГО ДЕФОРМУВАННЯ СХИЛУ ПІД ДІЄЮ СИЛОВИХ ТА ПРИРОДНІХ ФАКТОРІВ}

Планування будівництва в складних інженерно-геологічних умовах, до яких відносяться і зсувонебезпечні території, потребує детального аналізу існуючого стану схилу та прогнозу його поведінки в залежності від зміни природних і техногенних факторів. Таку можливість може забезпечити лише моделювання процесів деформування з використанням чисельних методів розрахунку.

На прикладі будівництва триповерхового котеджу на зсувонебезпечному схилі проведено аналіз умов експлуатації існуючих протизсувних споруд і визначена їх роль в забезпеченні стійкості схилу.

Попередній розрахунок стійкості схилу виконано методом круглоциліндричних поверхонь сковзання для грунтів природної вологості та у водонасиченому стані. Метод круглоциліндричних поверхонь $є$ спрощеним методом розрахунку стійкості схилів, що в умовах неоднорідного шаруватого схилу приводить до завищення його стійкості. Тому для визначення дійсного НДС схилу був розроблений розрахунковий профіль, за яким виконані декілька постановок наведеної задачі.

Розрахунок виконано на основі розробленої методики, представленої в роботах авторів статті. Напружено-деформований стан (НДС) схилу розглядається 3 використанням методу скінчених елементів (МСЕ) та його моментної схеми (МССЕ). Основа представляється у вигляді модифікованої моделі зміцнюваних грунтів 3 критерієм граничного стану МізесаШлейхера-Боткіна. При чисельній реалізації схил на основі інженерних вишукувань був представлений як скінченно-елементна дискретна модель із елементною сіткою, фрагмент якої є окремим інженерно-геологічним елементом.

Розглянутий в статті приклад методики розрахунку системи «підпірна споруданелінійна основа-будинок» дає можливість при варіантному проектуванні дати достовірну оцінку стану території та запропонувати ряд раціональних заходів щодо іiі інженерного захисту, що забезпечує надійну експлуатацію будівель і споруд.

Ключові слова: метод скінченних елементів, напіваналітичний метод скінченних елементів, зсувонебезпечні території, стійкість схилу, інженерний захист території.

\section{Solodei I.I., Petrenko E.Yu., Zatyliuk Gh.A.}

\section{STUDY OF PARAMETERS OF NONLINEAR SLOPE DEFORMATION UNDER THE ACTION OF POWER AND NATURAL FACTORS}

Construction planning in complex engineering and geological conditions, which include landslide-prone areas, requires a detailed analysis of the existing state of the slope and the forecast of its behavior depending on changes in natural and technogenic factors. This possibility can be provided only by modeling deformation processes using numerical calculation methods.

On the example of construction of a three-storey cottage on a landslide-prone slope, the analysis of the operating conditions of existing anti-landslide structures was carried out and their role in ensuring the slope stability was determined.

The preliminary calculation of the slope stability was performed by the method of round cylindrical sliding surfaces for soils of natural humidity and in water-saturated state. The method of round cylindrical surfaces is a simplified method of calculating the slopes stability, which in the conditions of heterogeneous layered slope leads to the overestimation of its stability. Therefore, to determine the actual NSDT of the slope, the calculation profile was developed, on which several formulations of the above problem were performed.

The calculation was performed on the basis of the developed methodology presented in the works of the article authors. The stress-strain state (SSS) of the slope is considered using the finite element method (FEM) and its torque circuit. The base is presented in the form of a modified model of fortified soils with the criterion of the limit state of Mises-Schleicher-Botkin. In numerical implementation, the slope on the basis of engineering surveys was presented as a finiteelement discrete model with an elemental grid, a fragment of which is a separate engineeringgeological element.

The considered in the article example of the method of calculation of the system «supporting structure-nonlinear base-house» gives the opportunity to give a reliable assessment of the territory state and offer a number of rational measures for its engineering protection, which ensures reliable operation of buildings and structures.

Keywords: finite element method, semi-analytical finite element method, landslide-prone areas, slope stability, engineering protection of the territory. 
Солодей И.И., Петренко Э.Ю., Затылюк Г.А.

\section{ИССЛЕДОВАНИЕ ПАРАМЕТРОВ НЕЛИНЕЙНОГО ДЕФОРМИРОВАНИЯ СКЛОНА ПОД ДЕЙСТВИЕМ СИЛОВЫХ И ПРИРОДНЫХ ФАКТОРОВ}

Планирование строительства в сложных инженерно-геологических условиях, к которым относятся и оползнеопасные территории, требует детального анализа существующего состояния склона и прогноза его поведения в зависимости от изменения природных и техногенных факторов. Такую возможность может обеспечить только моделирование процессов деформирования с использованием численных методов расчета.

На примере строительства трехэтажного коттеджа на оползнеопасном склоне проведен анализ условий эксплуатации существующих противооползневых сооружений и определена их роль в обеспечении устойчивости склона.

Предварительный расчет устойчивости склона выполнен методом круглоцилиндрических поверхностей скольжения для грунтов естественной влажности и в водонасыщенном состоянии. Метод круглоцилиндрических поверхностей является упрощенным методом расчета устойчивости склонов, который в условиях неоднородного слоистого склона приводит к завышению его устойчивости. Поэтому для определения действительного НДС склона был разработан расчетный профиль, по которому были выполнены несколько постановок приведенной задачи.

Расчет выполнен на основе разработанной методики, представленной в работах авторов статьи. Напряженно-деформированное состояние (НДС) склона рассматривается с использованием метода конечных элементов (МКЭ) и его моментной схемы (МССЕ). Основание представляется в виде модифицированной модели упрочняющегося грунта с критерием предельного состояния Мизеса-Шлейхера-Боткина. При численной реализации склон на основе инженерных изысканий был представлен как конечно-элементная дискретная модель с элементной сеткой, фрагмент которой является отдельным инженерногеологическим элементом.

Рассмотрен в статье пример методики расчета системы «подпорное сооружение нелинейное основание - дом» дает возможность при вариантном проектировании дать достоверную оценку состояния территории и предложить ряд рациональных мер по ее инженерной защите, что обеспечивает надежную эксплуатацию зданий и сооружений.

Ключевые слова: метод конечных элементов, полуаналитический метод конечных элементов, оползнеопасные территории, устойчивость склона, инженерная защита территории.

\section{УДК 539.3}

Солодей I.I., Петренко Е.Ю., Затилюк Г.А. Дослідження параметрів нелінійного деформування схилу під дією силових та природніх факторів // Опір матеріалів і теорія споруд: наук.-тех. збірн. - К.: КНУБА.2021. - Вип. 107. - С. 35-44. - Англ.

На прикладі будівниитва триповерхового котеджу на зсувонебезпечному схилі проведено аналіз умов експлуатачії існуючих протизсувних споруд і визначена їх роль в забезпеченні стійкості схилу. Показана ефективність запропонованої методики розрахунку на основі метода скінченних елементів (МСE) з урахуванням теорії зміцнюваних трунтів.

Іл. 8. Бібліогр. 7 назв.

\section{UDC 539.3}

Solodei I.I., Petrenko E.Yu., Zatyliuk Gh.A. Study of parameters of nonlinear slope deformation under the action of power and natural factors // Strength of Materials and Theory of Structures: Scientific-and-technical collected articles. - K.: KNUBA. 2021. - Issue107. - P. 35-44.

On the example of construction of a three-storey cottage on a landslide-prone slope, the analysis of the operating conditions of existing anti-landslide structures was carried out and their role in ensuring the slope stability was determined. The efficiency of the proposed calculation method based on the finite element method (FEM) is shown, taking into account the theory of reinforced soils.

Fig. 8. Ref. 7 


\section{УДК 539.3}

Солодей И.И., Петренко Э.Ю., Затылюк Г.А. Исследование параметров нелинейного деформирования склона под действием силовых и природных факторов // Сопротивление материалов и теория сооружений. - 2021. - Вып. 107. - С. 35-44.

На примере строительства трехэтажного коттеджа на оползнеопасном склоне проведен анализ условий эксплуатации существующих противооползневых сооружений и определена их роль в обеспечении устойчивости склона. Показана эффективность предложенной методики расчета на основе метода конечных элементов (МКЭ) с учетом теории упрочняюшегося грунта.

Ил. 8. Библиогр. 7 назв.

Автор: доктор технічних наук, професор, професор кафедри будівельної механіки Солодей Іван Іванович

Адреса: 03680 Украӥна, м. Київ, Повітрофлотський проспект 31, Київський національний університет будівниитва і архітектури

Робочий тел.: +38 (044) 241-55-55

Мобільний тел.: +38 (050)357-44-90

Email: solodei.ii@knuba.edu.ua

ORCID ID: https://orcid.org/0000-0001-7638-3085

Автор: кандидат технічних наук, доцент, дочент кафедри геотехніки Петренко Едуард Юрійович

Адреса: 03680 Украӥна, м. Київ, Повітрофлотський проспект 31, Київський національний університет будівниитва і архітектури

Email: petrenko.ey@knuba.edu.ua

ORCID ID: https://orcid.org/0000-0002-9792-4757

Автор: доктор філософії в прикладній механіці, доцент кафедри будівельної механіки Затилюк Герман Анатолійович

Адреса: 03680 Украӥна, м. Київ, Повітрофлотський проспект 31, Київський національний університет будівниитва і архітектури

Мобільний тел.: +38 (099) 11-00-564

Email: zatyliuk.ha@knuba.edu.ua

ORCID ID: https://orcid.org/0000-0003-0392-2214 